\title{
Evaluation of Waste Potential in TPST Bantargebang Through Modified Triangular Method
}

\author{
Budiman R Saragih", , Sri R H Siregar ${ }^{1}$, and Adi Surjosatyo $^{1}$ \\ ${ }^{1}$ Departement of Mechanical Engineering Universitas Indonesia, Kampus UI Depok 16426, Indonesia.
}

\begin{abstract}
The landfill gas technology has been implemented in some landfill in urban area of Indonesia. Bantargebang integrated waste treatment (TPST Bantargebang) is the first landfill completed with energy recovery facility, landfill gas technology. TPST Bantargebang power plant established in 2010 and supplied electricity to grid. The electrical energy supplied tend to decrease and only reaches $2.4 \mathrm{GWh}$ in 2017. Energy potential is important to evaluated for knowing the performance of TPST Bantargebang power plant. By using Modified Triangular Method, obtained the results that the electricity energy potential equal to $4.5 \mathrm{GWh}$. The calculation also estimate the emission reduction potential about $4325.88 \mathrm{tCO}_{2}$ /year, and economic potential from sales of electricity about 3.7 billion rupiah.
\end{abstract}

\section{Introduction}

The amount of waste generating in Indonesia is growing constantly every year from 65.08 million tons in year 2015 to 66.92 million tons in 2017. This number is expected to reach 68.81 million tons in 2019[1].

The increasing trend of waste amount nationally also occurs in the area of DKI Jakarta. Based on The Environmental Office DKI Jakarta data, the total waste processed in the Batargebang landfill area has increased constantly in a decade from about 1.85 million tons to 2.51 million in years 2010 to 2017 .

This means that various waste management activities, such as waste segregation, waste bank, or 3R (reduce, reuse and recycle) activities from waste source site have not been effective in reducing waste treatment activities in TPA Bantargebang. There are some waste management activities in TPA Bantargebang landfill like composting, waste water treatment, recycling plastic material, sanitary landfill of disposal and converting landfill gas into electricity. TPA Bantargebang landfill treats the average waste 7,924 tons per day in 2017 and most of the waste buried as disposal in TPA Bantargebang landfill area. This situation appeared in national scale as well where the data of the Adipura Secretariat of Ministry of Environmental and Forestry in 2015 shows $66.39 \%$ of waste just buried in landfill as disposal. This situation certainly affects the landfill lifetime so needed the specific technology that can reduce the waste massively and contribute to the sustainability waste treatment in term of environmental, social and economic aspect.
This paper is the first part of three writings. In this section the discussion is focused on the energy potential of waste at the TPA Bantargebang landfill and comparing it with the current condition of waste to energy, especially waste to electricity in the location. All of waste data such as composition, characteristic or treatment are based on location.

The second paper will examine the environmental, and economic assessment of landfill gas (LG) technology, the current technology, with life cycle assessment (LCA) methods. In addition, the second paper will discuss the implementation of anaerobic digester $(\mathrm{AD})$ technology and comparing $\mathrm{LG}$ and $\mathrm{AD}$ technology with LCA method, both of environmental and economy aspect.

The next discussion in third paper is development life cycle sustainability assessment (LCSA) system. The system is an indicator of sustainability of waste to energy which is developed based on specific characteristic of waste treatment in Indonesia. TPA Bantargebang is chosen as a benchmarking location and the system will be implemented in several major cities in Indonesia.

\section{Literature review}

Several study about waste to energy have been done to optimize the potential of technology. Some authors define the potential of technology in term of electrical generation, greenhouse gas emission, economic benefit, and social upgrading.

\footnotetext{
Corresponding author: budiman.ricardo@ui.ac.id
} 
Ali Rajaeifar et al compare anaerobic digestion, incineration, and pyrolysis-gasification to assess potential of electrical generation and greenhouse gas emission reduction. They compare the install technology at some country and assess potential electricity and greenhouse gas emission in Iran using LCA method [2]. Sora $\mathrm{Yi}$ et al evaluates the energy recovery and greenhouse gas reduction potentials of landfill gas recovery, incineration, recycling organic waste and recycling solid waste in Korea. They using IPCC model to estimate the methane generation as the reference for estimate the other potential [3]. Monojit Chakrabortya et al have done the time series comparison by using for different methane estimating methodologies. The research obtained that modified triangular methodology (MTM) [4] shows the highest estimated CH4 emission potential with the most uniformly improved graphical form compared to others

Landfill gas generation model could be accomplished using zero order, first order, second order, and/or multiphase generation models [5]. Modified triangular method (MTM) is one of method for modeling landfill gas. This method assumes two phase degradation, the first phase deposition increase linearly to maximum point, and second phase deposition decrease lineearly to zero. This model approach to triangular form [6].

Ayodele et al evaluate potential of energy saving, economic and environmental benefit from recyclable material which decomposite in municipal solid waste in Nigeria. They using local approach to estimate energy, economic, and environment potential [7].

\section{Methodology}

\subsection{Field investigation}

Bantargebang landfill dedicated for Jakarta city, located in suburban area, Bekasi city. Bantargebang adopt sanitary landfill and applied waste to energy technology using landfill gas recovery method.

Investigation of this research bounded for potential energy, environment, and economic at landfill area in operation time. This research evaluate the potential using the data from field investigation.

\subsection{Estimation of landfill gas generation}

Modified Triangular Method (MTM) for estimate of landfill gas generation was used in this study. The estimation derived from rapidly and slowly decomposable organic constituents in municipal solid waste. Constituens clasified rapidly decomposable for decompose three months to five years and clasified slowly decomposable for decompose up to 50 years.

Triangular gas generation was developed by Tchobanoglous et al. (1993) [8]. Rapidly decomposable reach triangular gas generation until 5 years, and slowly decomposable reach triangular gas generation until 15 years. The cumulative area under rapidly and slowly decomposable equals the total gas generation from the waste.
Total gas generation from landfill consist not only methane gases, but also carbon dioxide and other trace gases. Methane generation is $45 \%-60 \%$ from total gas generation [9].

\subsection{Estimation of energy potential}

Potential of energy obtained in electrical energy generation each year $(\mathrm{kWh} /$ year). Equation 1 shown to estimate electrical energy from methane collected from landfill [10].

$$
E_{p(\operatorname{LFOTE})}=\frac{\varepsilon \times Q_{0} \times \varphi_{1}}{\varphi_{2}}
$$

Where $\varepsilon$ is the Lower Heating Value of methane, $\varphi_{1}$ is the electrical conversion efficiency for internal combustion engine, $\varphi_{2}$ is the conversion factor from MJ to $\mathrm{kWh}$ based on heat content of methane, and $\mathrm{Q}_{\mathrm{c}}$ is the average methane collection per year $\left(\mathrm{m}^{3} /\right.$ year), can be obtained using equation 2 :

$$
\mathrm{Q}_{\mathrm{c}}=\lambda \times \mathrm{Q}_{\mathrm{g}}
$$

Where $\mathrm{Q}_{\mathrm{g}}$ is average methane generation per year and $\lambda$ is collection efficiency. In this research used $\varepsilon$ $37.2 \mathrm{MJ} / \mathrm{kWh}, \varphi_{1} 33 \%$ or $0.33, \varphi_{2} 3.6$, and $\lambda 75 \%$ or $0.75[10]$.

\subsection{Estimation of environment potential}

The displacement electricity to renewable electricity from municipal solid waste contribute to reduce greenhouse gas emission that indicates with $\mathrm{CO}_{2}$ reduction. Potential of environment for this research defined from converting emission based on electricity coal power plant. Decreasing electricity from coal power plant inflict decrease of carbon dioxide emission. The avoidance of carbon dioxide is environment potential of this technology, and can be obtained using equation 3 [7].

$$
\mathrm{CO}_{2} \text { avoidance }=\mathrm{E}_{\mathrm{P}} \times \mathrm{CF}_{\mathrm{EC}}
$$

Where $E_{p}$ is electricity production from waste to energy technology, and $\mathrm{CF}_{\mathrm{EC}}$ is carbon emission factor of per $\mathrm{kWh}$ electricity production from coal. Carbon emission factor $0.951 \mathrm{~kg} \mathrm{CO}_{2} / \mathrm{kWh}$ used in this research based on location of grid facilities that supplied by energy generated.

\subsection{Estimation of economic potential}

Evaluation of economic potential only defined on sales electrical energy generated in this research. Since 2010, the TPST Bantargebang power plant and PT PLN (Persero) had the power purchase agreement on sales electrical tarif from renewable source to on grid facilities is Rp. $820,-/ \mathrm{kWh}$. 


\section{Result and discussion}

Waste generation to bantargebang landfill obtained from operator in landfill area. The waste generation increase each year can be shown in Figure 1.

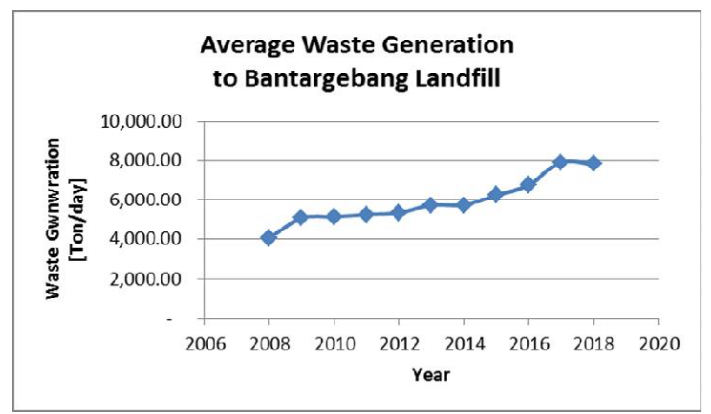

Fig 1. Average Waste Generation

In 2016 the average waste generation is 6758,76 tons/day, 2017 is 7924,61 tons/day, and 2018 is 7829,13 tons.day. Average waste generation of three last year used for calculate the potential energy, electricity, and economic.

Municipal solid waste constituents data obtained from filed investigation shown in Figure 2.

\section{Waste Constituents at Disposal}

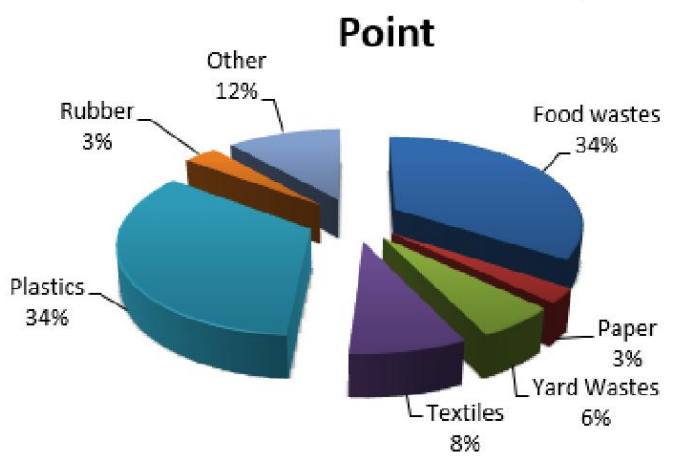

Fig 2. Waste Constituents at Disposal Point

Food waste and plastics (each 34\%) are the biggest waste constituent at disposal point. Textile $8 \%$, yard waste (include woods) $6 \%$, rubber $3 \%$, paper $3 \%$,and other (include dirt, ash, glass) $12 \%$. Assumed $60 \%$ of yard waste decomposed rapidly and $40 \%$ decomposed slowly.

From the waste composition and the waste chemical composition we get the waste decomposition rate shown in Table 1.

Table 1. Waste Decomposition Rate [11]

\begin{tabular}{|c|c|c|c|c|c|c|c|c|c|}
\hline \multirow{2}{*}{\multicolumn{2}{|c|}{ Waste Coposition }} & \multirow{2}{*}{$\begin{array}{c}\text { Net Weight } \\
(\mathrm{kg})\end{array}$} & \multirow{2}{*}{\begin{tabular}{|c|} 
Dry Weight \\
$(\mathrm{kg})$
\end{tabular}} & \multicolumn{6}{|c|}{ Chemical Composition } \\
\hline & & & & $\mathrm{c}$ & $\mathrm{H}$ & 0 & $\mathrm{~N}$ & $\mathrm{~s}$ & Ash \\
\hline \multirow{4}{*}{$\begin{array}{c}\text { Fast } \\
\text { decomposition }\end{array}$} & Food wastes & 34.3 & 10.3 & 4.94 & 0.66 & 3.87 & 0.27 & 0.04 & 0.51 \\
\hline & Paper & 2.7 & 2.5 & 1.10 & 0.15 & 1.12 & 0.01 & 0.01 & 0.15 \\
\hline & Cardboard & 0.0 & 0.0 & 0.00 & 0.00 & 0.00 & 0.00 & 0.00 & 0.00 \\
\hline & Yard Wastes & 3.5 & 1.4 & 0.67 & 0.08 & 0.53 & 0.05 & 0.00 & 0.06 \\
\hline \multicolumn{2}{|r|}{ Total } & 40.5 & 14.2 & 6.71 & 0.89 & 5.52 & 0.32 & \begin{tabular}{l|l}
0.05 \\
\end{tabular} & 0.73 \\
\hline \multirow{6}{*}{$\begin{array}{c}\text { Slow } \\
\text { decomposition }\end{array}$} & Textiles & 8.3 & 7.5 & 4.11 & 0.19 & 2.33 & 0.31 & 0.01 & 0.19 \\
\hline & Plast & 33.4 & 33.2 & 19.94 & 2.39 & 1.38 & 0.00 & 0.00 & 3.32 \\
\hline & Rubber & 3.4 & 3.4 & 2.61 & 0.34 & 0.00 & 0.07 & 0.00 & 0.34 \\
\hline & Leather & 0.0 & 0.0 & 0.00 & 0.00 & 0.00 & 0.00 & 0.00 & 0.00 \\
\hline & Yard Wastes & 2.32 & 0.928 & 0.44 & 0.06 & 0.35 & 0.03 & 0.00 & 0.04 \\
\hline & Wood & 0.0 & 0.0 & 0.00 & 0.00 & 0.00 & 0.00 & 0.00 & 0.00 \\
\hline & otal & $\begin{array}{l}47.96 \\
\end{array}$ & 44.99 & 27.11 & 3.28 & 10.26 & 0.44 & 0.01 & 3.89 \\
\hline
\end{tabular}

The constituents used to estimate gas generation with modified triangular method. Estimation of gas generation anually shown in Figure 3.

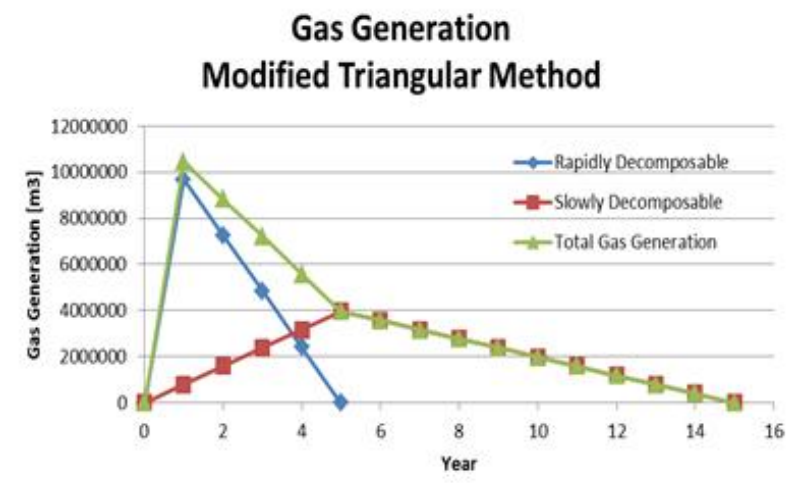

Fig 3. Estimation of Gas Generation

Total gas generation using MTM is $53.36 \times 10^{6}$ $\mathrm{m}^{3} /$ year, with the peak generation is $10.37 \times 10^{6} \mathrm{~m}^{3}$ at second year. Methane generation is $26.68 \times 10^{6} \mathrm{~m}^{3}$ assumed $50 \%$ from total gas generation.

Electrical energy generation calculated using equation 1 and 2 results $4548765.94 \mathrm{kWh} /$ year or 4.5 $\mathrm{GWh} /$ year. However, the operation only produce 2.4 $\mathrm{GWh} /$ year supplied to on grid electricity facilities.

Environment potential calculated using equation 3 results $4325876 \mathrm{~kg} \mathrm{CO}_{2}$ or $4325.88 \mathrm{tCO}_{2} /$ year. However, the record from field investigation mention average $\mathrm{CO}_{2}$ reduction by renewable electricity only $2430 \mathrm{tCO}_{2} /$ year.

Economic potential from sales of $4.5 \mathrm{GWh} /$ year of electricity is 3.7 billion rupiah. The economic potential can be increased up to 8.5 billion rupiah if the operator of TPST Bantargebang use presidential decree No. 35 year 2018 .

\section{Conclusion}

The energy potential of waste at TPST Bantargebang in 2017 is quite large, equivalent to $4.5 \mathrm{GWh}$ of electricity. However, the use of gas landfill technology is only capable to generate the electrical equivalent to $2.4 \mathrm{GWh}$ to be supplied to the local grid in the same year. Of course the power plant operators in TPST Bantargebang lost potential revenue of 1.78 billion rupiah during the year 2017. And also potential of the environment, which is proportionally with potential energy produced. Lost potential avoidance carbon dioxide reach until 1800 $\mathrm{tCO}_{2}$. To determine the performance of TPST Bantargebang power plants then the next is needed to do the assessment by life cycle assessment (LCA) method.

Furthermore, it is necessary to examine the development of waste-to-energy technology in the TPST Bantargebang and the closest technology is an anaerobic digester (AD). The $\mathrm{AD}$ technology will be compared to landfill gas (LG) technology with the LCA method to obtain the most optimized waste management at TPST Bantargebang. 
We would like to acknowledgement the support from Dinas Lingkungan Hidup dan Kebersihan DKI Jakarta as operator in Bantargebang landfill.

\section{References}

1. Ministry_of_Environmental_and_Forestry, The secretariat adipura report, internal report 2015 (unpublished report), 2015.

2. Rajaeifar, M.A., et al., Renewable and Sustainable Energy Reviews, Electricity generation and ghg emission reduction potentials through different municipal solid waste management technologies: A comparative review. 79: p. 414-439, (2017).

3. Yi, S., Y.-C. Jang, and A.K. An, Journal of Cleaner Production, Potential for energy recovery and greenhouse gas reduction through waste-to-energy technologies. 176: p. 503-511, (2018).

4. Chakraborty, M., et al., Atmospheric Environment, Methane emission estimation from landfills in delhi: A comparative assessment of different methodologies. 45(39): p. 7135-7142, (2011).

5. Majdinasab, A., Z. Zhang, and Q. Yuan, Reviews in Environmental Science and Bio/Technology, Modelling of landfill gas generation: A review. 16(2): p. 361-380, (2017).

6. Mor, S., et al., Science of the Total Environment, Municipal solid waste characterization and its assessment for potential methane generation: A case study. 371(1-3): p. 1-10, (2006).

7. Ayodele, T.R., M.A. Alao, and A.S.O. Ogunjuyigbe, Resources, Conservation and Recycling, Recyclable resources from municipal solid waste: Assessment of its energy, economic and environmental benefits in nigeria. 134: p. 165-173, (2018).

8. Tchobanoglous, G., H. Theisen, and S.A. Vigil, Integrated solid waste management: Engineering principles and management issues. 1993: McGraw-Hill.

9. Themelis, N.J. and P.A. Ulloa, Renewable Energy, Methane generation in landfills. 32(7): p. 1243-1257, (2007).

10. Ogunjuyigbe, A., T. Ayodele, and M. Alao, Renewable and Sustainable Energy Reviews, Electricity generation from municipal solid waste in some selected cities of nigeria: An assessment of feasibility, potential and technologies. 80: p. 149-162, (2017).

11. Environment_Office_of_DKI_Jakarta, Laporan pengukuran timbulan komposisi dan karakteristik sampah di tps dan tpst bantargebang, 2017. 